\title{
Cisterns as Vital Structures: Byzantine Cisterns and Subarachnoid Cisterns
}

\author{
Tayfun HAKAN \\ Fatih Sultan Mehmet Teaching and Research Hospital, Neurosurgery Clinic, Istanbul, Turkey \\ Corresponding author: Tayfun HAKAN tayfunhakan@yahoo.com
}

\section{ABSTRACT}

Water is essential for life. It is needed not only to survive but also to sustain daily life activities. The maintenance of daily life activities related to hygiene as well as prevention of epidemic diseases and accidents involving fire was as important in the past as today. Powerful empires built many open-air and covered cisterns for water reservation and constructed aqueducts to bring water from hinterland to these cisterns. The first prototypes of cisterns were constructed in the Neolithic age. Byzantine cisterns such as the Basilica Cistern and Aqueduct of Valens are excellent examples that are remnants from the past to present.

Similar to these social measures for water preservation, biological structures exhibit their own measures. In the human body, subarachnoid cisterns of central nervous system are the best-known cisterns, despite the presence of the cisterna chyli and Golgi body. The central nervous system produces and stores water in the form of cerebrospinal fluid in the subarachnoid cisterns for mechanical and immunological protection of the anatomical structures and for autoregulation of cerebral blood flow every day. Any condition that may adversely affect the cisterns, public or subarachnoid, may cause serious and irreversible damage to life. Hence, we should appreciate the importance of water for life; moreover, "if there is water there is life" is not a great prophecy.

KEYWORDS: Byzantium, Cisterna, Cisterna chyli, Golgi body, Subarachnoid cisterna

\section{INTRODUCTION}

$\mathrm{F}$ Tor all living organisms, plants, animals, or humans, water is essential for life on Earth. Providing water to the public has become one of the most important tasks. Cities have survived as long as they have had access to water resources, like living organisms. Throughout history, sieges have been made to seize the castles, with the anticipation that water would run out. To prevent this situation, different types of cisterns and aqueducts were constructed to store and transfer water from springs or subsurface sources (12).

Cisternal structures are also crucial for living beings. The subarachnoid cisterns and cisterna chyli in mammals $(20,22)$, and the Golgi body in plants and animals are examples of such storage receptacles (11).

Facts and/or coincidences/similarities that seem unrelated to each other may be the result of people's conscious or unconscious efforts throughout history. The word "cistern" is has been used to define two essential structures of life: the Byzantine and subarachnoid cisterns.

There are functional similarities between cisterns built by man and those that naturally exist in the human body. They are expected to protect and ensure the natural order of human life. After all, water is extremely valuable, and there should be no leakage in the cisterns. Cisterns are expected to be waterproof, whether they are created by humans or naturally exist living organisms.

Furthermore, an interesting and compelling resemblance can be established between the origination of both cistern structures; they require adequate time for formation and development. The first examples of manmade cisterns transitioned from hunter-gatherer to agricultural societies in the Neolithic Era (17). The advanced types of these cisterns emerged with time in history. Subarachnoid cisterns were formed with the

Tayfun HAKAN 이 : 0000-0003-1444-7076 
closure of the neural tube on approximately the $10^{\text {th }}$ day of the embryologic stage in humans; an adult mammalian subarachnoid cistern with CSF is fully formed after birth on around day 21 of infancy (2).

The purpose of this manuscript is to embark on a small journey to the realms of history and science, and arouse curiosity in readers about hypothetical subjects like functional, structural, and philosophical similarities. The manuscript does not provide a comprehensive presentation of water cisterns worldwide. Readers can find a detailed history of water cisterns in the literature for further reading $(12,17)$. This manuscript only provides certain examples of natural life cisterns and artificial water cisterns from İstanbul in the past and present.

\section{Cistern}

Cistern is a noun that originates from Latin word cisterna, which means "underground reservoir for water," and from cista meaning "chest or box" in Latin. Cistern has been used to describe a "natural or artificial receptacle for holding water or some other fluid" in mid-13th in old French literature (4). The first cisterns were constructed in the villages of Southwest Asia, including Taurus Mountains, Arabian Desert, and Mesopotamia in the Neolithic age $(17,18)$. The water cisterns later became popular in other regions around the world.

Cisterna in medicine means "a fluid-containing sac or cavity in an organism" (5). Subarachnoid cisterns of the nervous system, cisterna chyli, and Golgi body with individual stacks of cisternae are anatomic structures that correspond to this definition in living beings.

The cisterna chyli, which is also known as receptaculumchyli, is a dilated sac present at the lower end of the thoracic duct in mammals (20). The cisterna chyli is a dilatation, which forms the beginning of ductus thoracicus that transports the abdominal lymph to the subclavian vein (16). It is anteriorly located on the first and second lumbar vertebrae, posterior to the aorta, and adjacent to the right crus of the diaphragm.

The Golgi body or Golgi complex is an intracellular membranebound organelle comprising several small individual stacks of cisternae (11). The Golgi body performs the function of a cistern and also plays an important role in the transportation, modification, and packaging of proteins.

In medicine, the term cisterna is primarily used for any of the enlarged spaces below the arachnoid membrane in the central nervous system anatomy, called subarachnoid cistern. In mammalians, the maintenance of water and electrolyte balance is among the most vital functions. In the central nervous system of an adult human, a clear fluid, i.e., cerebrospinal fluid (CSF) is produced for the mechanical and immunological protection of anatomical structures along with the autoregulation of cerebral blood flow. In adults, $150 \mathrm{~mL}(0.35 \mathrm{~mL} / \mathrm{min})$ of CSF is produced at any point of time. Our body produces approximately $500 \mathrm{~mL}$ of CSF daily (19). Subarachnoid cisterns are responsible for the storage and circulationof CSF. The overproduction or any blockage in the circulation of CSF may lead to undesirable events. Any adverse effects of the subarachnoid cisterns may cause irreparable damage.

\section{Water Issue of Byzantine}

Water issue was one of the biggest problems, together with fire and epidemic diseases, of Constantinople, the capital of Byzantine, beginning from the establishment of the city (13). All these three issues were interrelated, and cisterns, with the amount of water held by them, were the lifesaver of the public. This issue was partly solved using a gravity-based system that brought water from the hinterland of the city.

The Roman Emperor Constantine the Great (272-337 AD; Latin: Flavius Valerius Aurelius Constantinus Augustus), also known as Constantine I, founded Constantinople, now Istanbul, in the year $330 \mathrm{AD}$. He built a 242-km-long water line from the Strandzha Mountains to Constantinople. Theodosius the Great (347-395 AD) and his son Arcadius (377-408 AD) improved this water line system. The aqueducts of Valens and Mazul are examples of the works of the Emperor Valen (328-378 AD) that are still standing in Istanbul. The aqueduct of Valens is known as "Bozdoğan Kemeri" in Turkish today (Figure 1). The arcade-shaped water lines running across the valleys became more or less symbol of almost all Roman aqueducts with their high standards, even though they were built in ancient times (12). These aqueducts are thought to have supplied the open cisterns of Aetius and Aspar, crossed the aqueduct of Valens, and terminated in the cistern of Philoxenos (8).

\section{Byzantine Cisterns}

Byzantines constructed many open-air and covered cisterns to store water to meet the needs of the citizens. Cisterns had waterproof linings that distinguished them from wells. The water storage capacity of the covered and open-air cisterns was approximately 200,000 and 800,000 tons, respectively. These were significant volumes for that era. Some of those cisterns have survived until today. The cisterns of Aetius and Aspar are examples of Constantinople's big open-air cisterns that have survived until today (13). Both these cisterns are located in the district of Fatih in Istanbul.



Figure 1: Aqueduct of Valens. https://en.wikipedia.org/wiki/ Valens_Aqueduct\#/media/File:Valens_aqu\%C3\%A4dukt02.jpg. Accessed March 07, 2020. 
The cistern of Aetius was built by Aetius, who was the prefect of the Constantinople in the year 421 . This cistern had a rectangular structure that was $244 \mathrm{~m}$ long and $85 \mathrm{~m}$ wide; its depth ranges from 13 to $15 \mathrm{~m}$, and it could hold approximately 250-300 tons of water. It has been used as a football stadium, known as "Vefa Stadı" or "Karagümrük Stadı," since 1928 (Figure 2) $(6,13)$.

The cistern of Aspar was built by general Aspar, who served Emperor Marcian (392-457 AD). It erected near the Yavuz Sultan Selim Mosque, overlooking the Golden Horn. The cistern has a square shape, with each side being $152 \mathrm{~m}$ long and covers an area of $23,100 \mathrm{sq}$. $\mathrm{m}$. The average depth lies between 10 and $11 \mathrm{~m}$, and the cistern can hold approximately 230-250 tons of water (7). It was known as "sunken garden" and used to grow vegetables during the Ottoman period. It is now used as a public park.

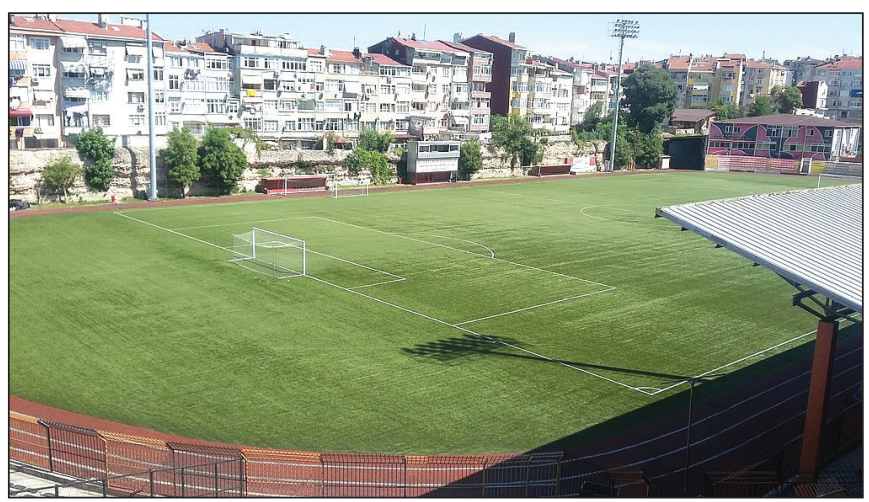

Figure 2: The cistern of Aetius. https://en.wikipedia.org/wiki/ Vefa_Stadium\#/media/File:Vefa_Stadyumu.jpg. Accessed March 07, 2020

\section{Basilica Cistern}

The Basilica Cistern is an important example of the covered cisterns of Byzantines. It is one of the most beautiful, magnificent, and famous ancient structures of istanbul. It is located in the southwest of Hagia Sophia. "Yerebatan Sarayı," which means subterranean palace, is the most used name for this cistern among the Turkish public because of its underground marble columns (1).

The cistern was constructed for Byzantium Emperor Justinianus I in the same year as Hagia Sophia in 537 (13). The cistern is $138 \mathrm{~m}$ long and $65 \mathrm{~m}$ wide and covers a 9,800 sq. $m$ rectangular area in total. The water storage capacity of the cistern is estimated to be 100,000 tons. The cistern has 336 columns, each $9 \mathrm{~m}$ high (Figure 3A). There is an interval of $4.80 \mathrm{~m}$ between the columns of 12 rows, each of which has 28 columns (9). The heads of the columns mainly reflect Ionic and Corinthian styles, with the exception of few Doric ones. Two columns located at the northwest edge of the cistern are supported by two Medusa heads-the great work of art from the Roman period (Figure 3B). Medusa is one of the three Gorgons from Greek mythology whose paintings and sculptures were being used to protect big structures and special venues at that time.

Water was transferred to the Basilica Cistern by means of aqueducts and waterways from the northern side of the city, which is today known as Belgrad Forest. Some parts of these can still be seen intact.

A French traveler P. Gyllius was the first to rediscover the Basilica Cistern and introduce it to the Western world between 1544 and 1550. The Basilica Cistern is currently a culture center of Istanbul Metropolitan Municipality, which serves as a venue for many national and international events.
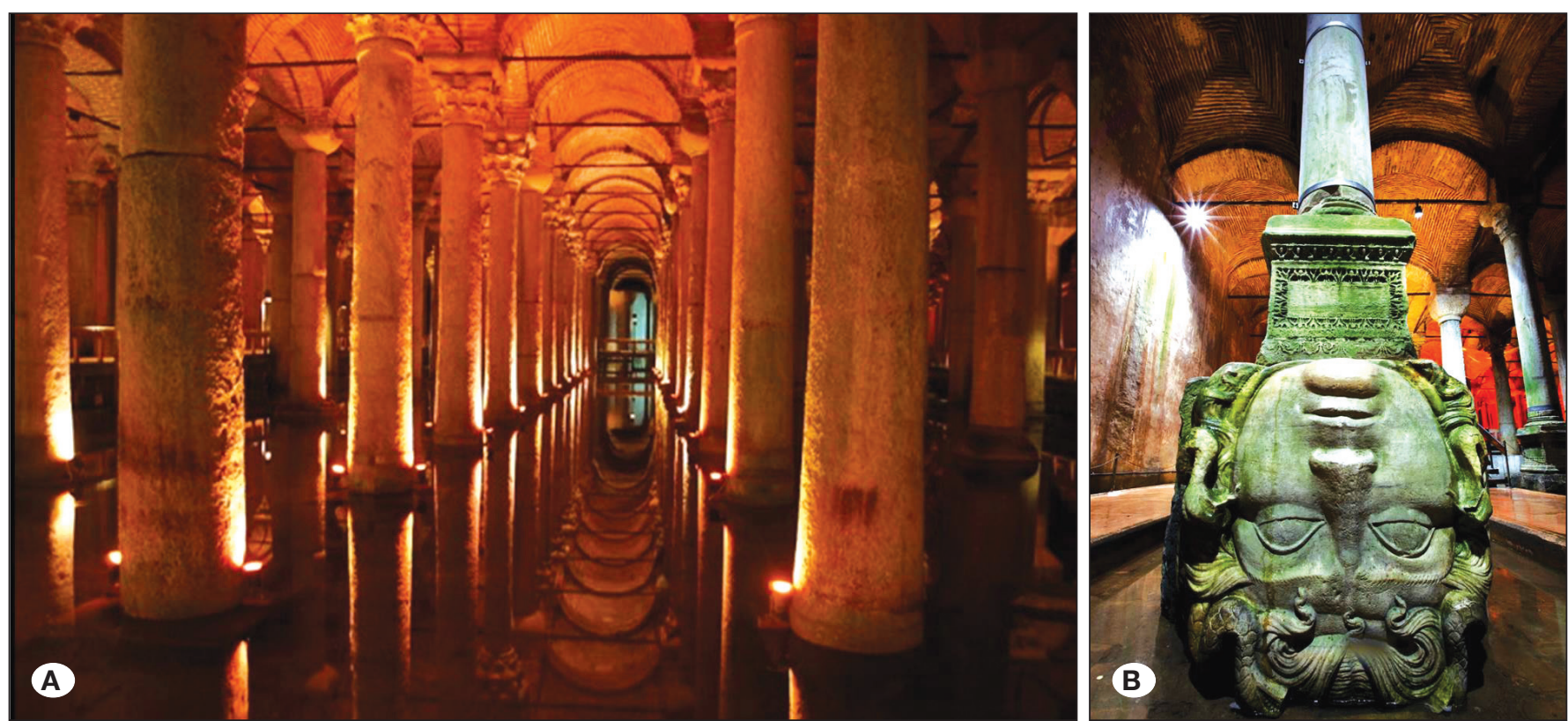

Figure 3: A) Columns of the Basilica cistern. https://en.wikipedia.org/wiki/Basilica_Cistern\#/media/File:Cisterna_Basilica_Junto_a_ Santa_Sofia_Estambul.JPG. Accessed March 07, 2020. B) The head of Medusa in the Basilica cistern. https://i.yerebatan.com/storage/ files/images/2018/11/22/04-hv2V.jpg. Accessed March 07, 2020. 


\section{Cistern of Philoxenos}

The cistern of Philoxenos is the second largest covered cistern of Byzantines. It was built by Philoxenos, who was a Roman senator during the time of the Emperor Constantine the Great in 4th century. It is thought that this structure was used as the water reservoir for Philoxenos' palace. It is $64 \mathrm{~m}$ long and 56 $\mathrm{m}$ wide and is supported by 224 marble columns, each 14-15 $\mathrm{m}$ tall; its water-holding capacity is 40 tons. Each column is a superposition of two columns, which are connected by a marble ring; of the 224 columns, 212 are still present. Greek letters engraved on some column bodies are still visible. These are thought to be the signs of Stonemasons' Guild who were involved in the construction of the cistern.

The Ottomans tailored the name "Binbirdirek" to this cistern due to the crowded columns and used this dim and cool place for silk production (13). "Binbir" (i.e., 1001) is a Turkish expression that is often used to express something that is varied and numerous (9). It is accepted that there was a connection of the Basilica and Theodosius Cisterns with the cistern of Philoxenos; however, there has been no comprehensive study on his subject (10). The cistern is used as a museum today.

\section{The Theodosius Cistern}

The Theodosius Cistern, also known as "Şerefiye Sarnıcı" in Turkish, is located in Fatih district near the two closed cisterns that are discussed above. It was built by the Emperor Theodosius II, between the years 428 and 443. It is smaller than the Basilica Cistern and cistern of Philoxenos and is $45 \mathrm{~m}$ long and $25 \mathrm{~m}$ wide. It serves as a museum today (10).

\section{The Ottomans}

The Ottomans were not willing to use the cisterns as water supply for drinking. According to them, stagnant water was unhealthy; it should come off the rock, pour from high, run fast and abundant, have a medium temperature, taste slightly sweet, and come from the wilderness (13). They gave importance to bring water carried through water lines, either using the previous structures or constructing new ones. They preferred building fountains.

\section{Subarachnoid Cisterns}

The central nervous system is covered by three layers of membranes, called meninges, from the inside to the outside: the pia mater, arachnoid mater, and dura mater. The enlarged anatomical spaces under the arachnoid membrane are referred to as cisterns of the brain and are filled with clear, colorless body fluid, i.e., CSF.

The membranes over the brain were known since the era of Claude Galen and Andreas Vesalius, but Gerard Blasius was the first who used the term arachnoid in 1666 (14). Raymundi Vieussens (1690), Frederik Ruysch (1697), Antonio Pacchioni (1729), Domenico Cotugno (1770), and Marie François Xavier Bichat (1802) contributed to the understanding of the meningeal anatomy (22). François Magendie was the first to provide the modern description of the subarachnoid space and to report that CSF in the subarachnoid space circulates
Table I: Yasargil's Classification of the Subarachnoid Cisterns (21).

\section{Supratentorial Cisterns}

\section{A. Anterior (parasellar) cistern}

1. Carotid cistern

2. Chiasmatic cistern

3. Lamina terminalis cistern

4. Olfactory cistern

5. Sylvian cistern

B. Lateral (parapedincular)

1. Crural cistern

2. Ambient cistern (anterior part)

C. Posterior (tentorial notch)

1. Quadrigeminal cistern

2. Velum interpositum cistern

D. Superior (callosal)

1. Corpus callosum cistern - anterior portion

2. Corpus callosum cistern - posterior portion

3. Hemispheric cistern

\section{Infratentorial Cisterns}

A. Anterior

1. Interpedinculer cistern

2. Prepontin cistern

3. Premedullary cistern

\section{B. Lateral}

1. Ambient cistern (posterior part)

2. (Superior) cerebellopontine cistern

3. Inferior cerebellopontine or lateral cerebello medullary cistern

\section{Posterior}

1. Cisterna magna

2. Superior cerebellar cistern

\section{Superior}

1. Vermian cistern

2. Hemispheric cistern

under pressure and communicates in all areas. Magendie used the term "confluens" for the cisterns, whereas Victor von Bruns (1854) and Hubert von Luschka (1855) preferred the term "subarachnoid sinus" for the subarachnoid enlargements described by them (3).

Axel Key and Gustaf Retzius were the first to use the term "cisterna" in their comprehensive work on the subarachnoid structures (14). They described and named cisterna cerebellomedullaris, cisterna pontis with a pars medialis and partes laterals, cisterna intercruralis, cisterna chiasmatis, cisterna laminae cinereae terminalis, cisterna corporiscallosi or spatiumsubarachnoid alecorporiscallosi, spatiumsubarachnoidalecorporumquadrigeminorum, cisterna ambiens, cisterna fossae Sylvii, and velum triangulare. Cisterna cerebellomedullaris, known as cisterna magna, is the largest and most well-studied cistern of the central nervous system. It is located in the posterior fossa between the cerebellum, upper spinal cord, and lower medulla. 
Jones Quain (1844), Albert von Kölliker (1850), and Rudolf Ludwig Carl Virchow (1854) provided valuable information about the meningeal anatomy.

Walter Edward Dandy injected air into the subarachnoid space, aiming to show the cerebral ventricles, and found that basal subarachnoid cisterns could also be demonstrated in the same manner in 1919. Charles Locke and Howard Christian Naffziger (1924), Davidoff and Dyke (1930), Spatz and Stroescu (1934), Robertson (1940), Ruggiero (1958), B. Liliequist (1959), Leighton (1971), and Wilson (1972) were the other researchers who studied the cisternae anatomy (22).

Despite an initial description by Key and Retzius in 1875, Liliequist precisely studied the arachnoid membrane and thechiasmatic, interpeduncular, and prepontine cisterns in his studies on pneumoencephalography in cadavers in 1956 (15). The arachnoid membrane is well known among neurosurgeons as the Liliequist membrane while performing the puncture of the floor of the third ventricle to create communication between the third ventricle and the basal cisterns.

Modern intracranial microneurosurgical procedures have become possible due to the accumulation of knowledge about the topographical anatomy of the basal cisterns and its variations (22). Cisterns contain arteries, veins, and cranial nerves that are floating in the cerebrospinal liquid. Yasargil made a huge contribution to the modern understanding of the operative subarachnoid cistern anatomy with an excellent classification of these subarachnoid cisterns (Table I) (21). He explained the detailed construction of cisterns and arachnoid fibers along with their variations. Thus, several intracranial surgeries can be performed safely - with less blood loss and without trauma-in the subarachnoid region (21).

\section{CONCLUSION}

Water is essential, as it is the basis of life. Human beings themselves are more fortunate than human communities. The nervous system itself produces water that is necessary for its life; furthermore, the nervous system stores water in its own reservoirs, the subarachnoid cisterns.

Humans have tried to gain access to water sources throughout the history. The man-made artificial cisterns and aqueducts were used appropriately throughout history. It is not a prophecy to say that water will be the cause of conflicts in the future. It is obvious that different types of cisternal structures will be public's agenda in the future, as they were in the past.

We should be grateful to the founders of artificial cisterns and water supply systems and should be aware of the value of the natural subarachnoid cisterns. Furthermore, we should try to maintain these artificial and natural cisterns in working and healthy states, respectively.

\section{REFERENCES}

1. About Us: In the Depths of History [YerebatanSarnıcı web site]. Available at: https://www.yerebatan.com/en/about-us. Accessed August 25, 2019
2. Altafulla J, Bordes S, Jenkins S, Litvack Z, Iwanaga J, Loukas M, Tubbs RS: The basal subarachnoid cisterns: Surgical and anatomical considerations. World Neurosurg 129:190-199, 2019.

3. Chapter 2: Anatomy and Roentgen Appearance of the Cisterns. Acta Radiologica 47 Sup 151:15-104, 1959. Available at: https://doi.org/10.3109/00016925909176029

4. Cistern. [Dictionary by Merriam-Webster web site]. Available at: https://www.merriam-webster.com/dictionary/cistern. Accessed August 25, 2019

5. Cistern. [Online Etymology Dictionary web site]. Available at: https://www.etymonline.com/word/cistern. Accessed August 25, 2019

6. Cistern of Aetius. [Wikipedia web site]. Available at: https:// en.wikipedia.org/wiki/Cistern_of_Aetius. Accessed March 07, 2020

7. Cistern of Aspar [Wikipedia web site]. Available at: https:// en.wikipedia.org/wiki/Cistern_of_Aspar. Accessed March 31, 2020

8. Cisterns of Byzantine Constantinople. [The Byzantine Legacy web site]. Available at: https://www.thebyzantinelegacy.com/ cisterns. Accessed August 31, 2019

9. Cistern of Philoxenos. [Wikipedia web site]. Available at: https://en.wikipedia.org/wiki/Cistern_of_Philoxenos.Accessed March 07, 2020

10. Date on the face of the day: Cheers cistern. [ŞerefiyeSarnıc web site]. Available at: https://www.serefiyesarnici.istanbul/ en/about-us. Accessed August 31, 2019

11. Dupree P, Sherrier DJ: The plant Golgi apparatus. Biochim Biophys Acta 1404:259-270, 1988

12. Fahlbusch H, Lübeck F: Municipal water supply in antiquity [web site]. June, 2008. Available at: http://www.romanaqueducts. info/webteksten/waterinantiquity.htm Accessed February 17, 2020

13. Hürel H: Touring İstanbul my eyes open. İstanbul: Dharma, 2005 (in Turkish)

14. Key EAH, Retzius MG: Studien in der Anatomie des Nerven Systems und des Bindegewebes. Stockholm: Samson \&Wallin, 1875

15. Liliequist B: The anatomy of the subarachnoid cisterns. Acta Radiol 46: 61-71, 1956

16. Loukas M, Wartmann CT, Louis RG Jr, Tubbs RS, Salter EG, Gupta AA, Curry B: Cisterna chyli: A detailed anatomic investigation. Clin Anat 2:683-688, 2007

17. Mays L, Antoniou GP, Angelakis AN: History of water cisterns: Legacies and lessons. Water 5:1916-1940, 2013

18. Miller R: Water use in Syria and Palestine from the Neolithic to the Bronze Age. World Archaeol 11: 331-341, 1980

19. Pople IK: Hydrocephalus and shunts: What the neurologist should know. J Neurol Neurosurg Psychiatry 73:i17-i22, 2002

20. Rusznyak I, Földi M, Szabo G: Anatomy of the main lymphatic trunks. In: Lymphatics and Lymph Circulation: Physiology and Pathology. Oxford: Pergamon Press, 1967:77-78

21. Yasargil MG: Microneurosurgery. Vol:1. Stuttgart, New York: Thieme, 1984

22. Yasargil MG, Kasdaglis K, Jain KK, Weber HP: Anatomical observations of the subarachnoid cisterns of the brain during surgery. J Neurosurg 44:298-302, 1976 